\title{
Ruminal Phosphorus Disappearance from Corn and Soybean Feedstuffs ${ }^{1}$
}

\author{
K. Mjoun, K. F. Kalscheur, ${ }^{2}$ A. R. Hippen, and D. J. Schingoethe \\ Dairy Science Department, South Dakota State University, Brookings 57007
}

\begin{abstract}
Byproducts of corn and soybeans have high phosphorus $(\mathrm{P})$ content, but little is known about their $\mathrm{P}$ disappearance in the rumen of lactating dairy cows. In situ disappearance of $\mathrm{P}$ from corn and soybean feedstuffs was determined in 2 experiments. In the first experiment, 3 ruminally cannulated lactating dairy cows were used to estimate in situ $\mathrm{P}$ disappearance of 9 feed ingredients that included 3 sources of dried distillers grains with solubles (DDG; DGa, DGb, DGc), corn, corn germ, solvent-extracted soybean meal, (44\% CP; SBM), expeller soybean meal (SoyPlus; SP), extruded soybeans (ES), and soyhulls (SH). Nylon bags were incubated in the rumen of each cow for $2,6,12,18,24$, 36 , and $48 \mathrm{~h}$. The water-soluble fraction of $\mathrm{P}\left(\mathrm{A}_{\mathrm{P}}\right)$ was greatest in DDG (mean $82.1 \%$ ) followed by corn germ (77\%), with SH having the least $\mathrm{A}_{\mathrm{P}}$ among all feedstuffs $(45 \%)$. The remaining feedstuffs (SBM, SP, ES, and corn) were similar in $\mathrm{A}_{\mathrm{P}}(64.2 \%)$. The slowly available fraction of $\mathrm{P}\left(\mathrm{B}_{\mathrm{P}}\right)$ was greatest in $\mathrm{SH}(45.6 \%)$, lowest in DDG (13.5\%), and intermediate, averaging $31.4 \%$, in SBM, ES, SP, and corn. The effective disappearance of $\mathrm{P}\left(\mathrm{ED}_{\mathrm{P}}\right)$ was greatest for DDG $(93.5 \%)$, whereas corn germ, ES, SBM, and SP followed with an $\mathrm{ED}_{\mathrm{P}}$ of 93.3, 88.0, 87.5, and $87.0 \%$, respectively. The $\mathrm{ED}_{\mathrm{P}}$ was less for corn and $\mathrm{SH}$ than for the other feedstuffs at 83.3 and $69.1 \%$, respectively. Rate of $\mathrm{P}$ disappearance was similar for all feedstuffs $(16.2 \% / \mathrm{h})$. In the second experiment, 3 new sources of DDG (DG1, DG2, and DG3), and one wet distillers grains with solubles (WDG) source were incubated for $3,6,12,24$, and $36 \mathrm{~h}$ on replicate days in the rumen of 2 cannulated lactating dairy cows. Fraction $A_{P}$ varied from 82.7 to $90.3 \%$, with that in WDG being the least soluble. The WDG source had a greater $\mathrm{B}_{\mathrm{P}}$ fraction (15.8\%) compared with the DDG sources (9.5\%). The WDG had the lowest $\mathrm{ED}_{\mathrm{P}}(88.1 \%)$, whereas the DDG varied from 89.7 to $92.7 \%$. Corn and soybean byproducts tested, with the exception of $\mathrm{SH}$,
\end{abstract}

\footnotetext{
Received September 13, 2007.

Accepted June 14, 2008.

${ }^{1}$ Published with the approval of the director of the South Dakota Agricultural Experiment Station as Publication Number 3600 of the Journal Series.

${ }^{2}$ Corresponding author: kenneth.kalscheur@sdstate.edu
}

have high ruminal $\mathrm{P}$ disappearance as measured with the Dacron bag technique.

Key words: ruminal phosphorus disappearance, in situ, feedstuffs, distillers grains

\section{INTRODUCTION}

Given the role of phosphorus $(\mathrm{P})$ in environmental pollution and the significant cost of adding inorganic $\mathrm{P}$ to the dairy ration, it is critical that dietary $\mathrm{P}$ not exceed the requirement of the animal. High dietary $\mathrm{P}$ concentrations can lead to excess $\mathrm{P}$ consumption and high $\mathrm{P}$ concentrations in wastes. Excess $\mathrm{P}$ from confined livestock operations has become a major environmental concern because of its harmful effects on surface water. Extensive data exist on $\mathrm{P}$ disappearance from mineral supplements (NRC, 2001) and to some extent from forages (Emanuele and Staples, 1990; Martz et al., 1990; Flachowsky et al., 1994), but data on ruminal disappearance from concentrate sources are limited (Bravo et al., 2000; Hristov et al., 2004). There are large differences in $\mathrm{P}$ solubility in different feedstuffs. Ruminal $\mathrm{P}$ release varied from $64 \%$ for rapeseed meal to $89 \%$ for wheat (Bravo et al., 2000). Concentrates account for as much as $60 \%$ of DM and between 60 and $80 \%$ of the total $\mathrm{P}$ in dairy rations. Particularly, byproducts from ethanol plants, such as wet distillers grains with solubles (WDG) and dried distillers grains with solubles (DDG), are rich in P content and are increasingly used in dairy rations. Consequently, it is important to quantify their $\mathrm{P}$ availability to formulate rations that are sufficient but do not exceed the requirement of the animal.

Recent research in pigs demonstrated that the apparent total tract digestibility of $\mathrm{P}$ is greater in $\mathrm{DDG}$ than in corn (Pedersen et al., 2007). It has been hypothesized that the phytate phosphorus (PP) in corn undergoes hydrolysis during the fermentation process in the ethanol plant resulting in $\mathrm{P}$ in distillers grains that is highly soluble. If true, the nutritional value of distillers grains would be increased when it is fed to meet the $\mathrm{P}$ requirement of the animal, but would be detrimental to the environment if overfed.

In general, there is limited information regarding ruminal P disappearance of concentrate feedstuffs com- 
monly used in dairy cow diets. Therefore, the objective of this study was to assess ruminal $\mathrm{P}$ disappearance of corn and corn byproducts compared with different soybean feedstuffs.

\section{MATERIALS AND METHODS}

\section{Feeds and In Situ Procedures}

Experiment 1. The purpose of experiment 1 was to compare $\mathrm{P}$ disappearance from corn and corn byproducts to various soybean feedstuffs. The in situ procedure was conducted using 3 lactating dairy cows (averaging 235 DIM and $25 \mathrm{~kg} / \mathrm{d}$ of milk) fitted with rumen cannulas. Animals were fed, for ad libitum consumption, a diet containing 50:50 forage to concentrate ratio (Table 1). Nine feedstuffs were evaluated including 3 different DDG from 3 commercial ethanol plants (DGa, DGb, and DGc), ground corn, corn germ (CG; Poet Nutrition, Sioux Falls, SD), and 4 soybean products that included solvent-extracted soybean meal (SBM; 44\% CP), expeller soybean meal (SP; SoyPlus, West Central Soy, Ralston, IA), extruded soybeans (ES), and soyhulls (SH). All feed ingredients, with the exception of DDG samples, were ground to pass a 2-mm screen in a Wiley mill (Arthur H. Thomas, Philadelphia, PA). Grinding distillers grains may negate some of the physical properties that affect feed degradability in the animal such as moisture content and microbial access to the protein sources (Stern et al., 1994) and ultimately P release from feedstuffs. Five grams (asfed basis) of each feedstuff was weighed into duplicate Dacron bags measuring $10 \times 20 \mathrm{~cm}$ with a pore size of $53 \pm 10 \mu \mathrm{m}$ (Ankom Technology, Fairport, NY) and heat sealed. Before incubation, duplicate samples of each feedstuff were soaked in approximately $39^{\circ} \mathrm{C}$ water for $15 \mathrm{~min}$. All sets of Dacron bags were placed in a larger, weighted mesh bag $(36 \times 42 \mathrm{~cm})$ that was suspended below the particulate mat layer in the ventral sac of the rumen. Bags were incubated in the rumen for 2,6 , $12,18,24,36$, and $48 \mathrm{~h}$. Bags were placed in the rumen in reverse order of sampling time so that all bags were removed from the rumen concurrently. The zero-hour bags were not placed in the rumen but was otherwise treated similarly. Blank bags in duplicate corresponding to each time point were placed in the rumen to correct for material accumulated in the bag during the incubation period. Following rumen incubation, the mesh bag containing all Dacron bags was rinsed with cold water to remove particulate matter, and the Dacron bags were removed and rinsed in a domestic washing machine under the delicate setting with warm water for approximately $5 \mathrm{~min}$ before draining. The cycle was repeated until effluent water remained clear.
Experiment 2. This experiment was conducted to determine if ruminal $\mathrm{P}$ disappearance from distillers grains varies by source. Samples used in this experiment were previously examined for protein degradability by Kleinschmit et al. (2007). Three sources of DDG (DG1, DG2, and DG3) and one source of WDG were tested for $\mathrm{P}$ disappearance in the rumen. Sources DG1, DG2, and DG3 in this study correspond to DG1, DG4, and DG5 in Kleinschmit et al. (2007). Samples of DG1 and DG2 were obtained from different ethanol plants, whereas DG3 and WDG originated from the same ethanol plant and were processed using similar procedures, except that DG3 was dried. Chemical

Table 1. Ingredients and chemical composition of the total mixed diet fed to cows during in situ experiments 1 and 2 (DM basis)

\begin{tabular}{|c|c|c|}
\hline Ingredient & Experiment 1 & Experiment 2 \\
\hline Corn silage & 26.3 & 21.7 \\
\hline Alfalfa hay & 21.4 & 12.2 \\
\hline Alfalfa haylage & - & 6.63 \\
\hline Wet distillers grains & 5.97 & 8.28 \\
\hline High moisture corn & 16.2 & 18.7 \\
\hline Ground corn, shell & 7.29 & 6.07 \\
\hline Soybean meal, $44 \%$ CP & - & 3.23 \\
\hline Expellers soybean meal ${ }^{1}$ & 4.43 & 4.56 \\
\hline Fish meal & 0.75 & 0.40 \\
\hline Whole cottonseed & 8.96 & 8.90 \\
\hline Rumen inert fat ${ }^{2}$ & 0.80 & 1.28 \\
\hline Liquid supplement ${ }^{3}$ & 4.06 & 4.23 \\
\hline Calcium carbonate & - & 0.97 \\
\hline Limestone & 0.58 & - \\
\hline Pork meat and bone meal & 1.19 & 0.64 \\
\hline Sodium bicarbonate & 0.54 & 0.57 \\
\hline Salt & 0.41 & 0.50 \\
\hline Mineral and vitamin premix ${ }^{4}$ & 0.21 & 0.31 \\
\hline Yeast culture $^{5}$ & 0.19 & 0.21 \\
\hline Magnesium oxide & 0.16 & 0.17 \\
\hline Feed additive $^{6}$ & - & 0.15 \\
\hline Urea & - & 0.17 \\
\hline Se yeast ${ }^{7}$ & - & 0.05 \\
\hline Trace mineral complex ${ }^{8}$ & 0.05 & 0.05 \\
\hline Vitamin E premix (44,000 IU/kg) & 0.02 & 0.02 \\
\hline \multicolumn{3}{|l|}{ Chemical composition } \\
\hline DM, \% & 46.3 & 42.0 \\
\hline $\mathrm{CP}, \%$ of $\mathrm{DM}$ & 16.7 & 17.7 \\
\hline NDF, \% of DM & 29.0 & 30.2 \\
\hline $\mathrm{ADF}, \%$ of $\mathrm{DM}$ & 18.8 & 18.8 \\
\hline $\mathrm{Ca}, \%$ of $\mathrm{DM}$ & 0.80 & 0.92 \\
\hline $\mathrm{P}, \%$ of DM & 0.41 & 0.40 \\
\hline
\end{tabular}

${ }^{1}$ SoyPlus (West Central Soy, Ralston, IA).

${ }^{2}$ Megalac-R (Church \& Dwight Co. Inc., Princeton, NJ).

${ }^{3}$ Energizer 4-19W (Quality Liquid Feeds, Dodgeville, WI).

${ }^{4}$ Contained $10 \% \mathrm{Mg} ; 2.6 \% \mathrm{Zn} ; 1.7 \% \mathrm{Mn} ; 4,640 \mathrm{mg} / \mathrm{kg}$ of Fe; $4,712 \mathrm{mg} /$ $\mathrm{kg}$ of Cu; $396 \mathrm{mg} / \mathrm{kg}$ of I; $119 \mathrm{mg} / \mathrm{kg}$ of Co; $140 \mathrm{mg} / \mathrm{kg}$ of Se; $2,640,000$ $\mathrm{IU} / \mathrm{kg}$ of vitamin A; 528,000 IU/kg of vitamin D3; and 10,560 IU/kg of vitamin E (Land O' Lakes Inc., St. Paul, MN).

${ }^{5}$ Diamond V XP (Diamond V Mills Inc., Cedar Rapids, IA).

${ }^{6}$ MTB-100, an esterified glucomannan processed from yeast cell walls (Alltech Biotechnology, Nicholasville, KY).

${ }^{7} 600$ ppm Se yeast (Alltech Biotechnology).

${ }^{8}$ Zinpro 4-Plex contained $2.53 \% \mathrm{Zn}$; $1.40 \% \mathrm{Mn}$; $0.88 \% \mathrm{Cu} ; 0.18 \%$ Co; 8.31\% Met; and 3.80\% Lys (Zinpro Corp., Eden Prairie, MN). 
Table 2. Chemical composition of dried distillers grains with solubles (DGa, DGb, and DGc), corn, corn germ (CG), soybean meal (SBM), SoyPlus (SP), extruded soybeans (ES), and soyhulls (SH)

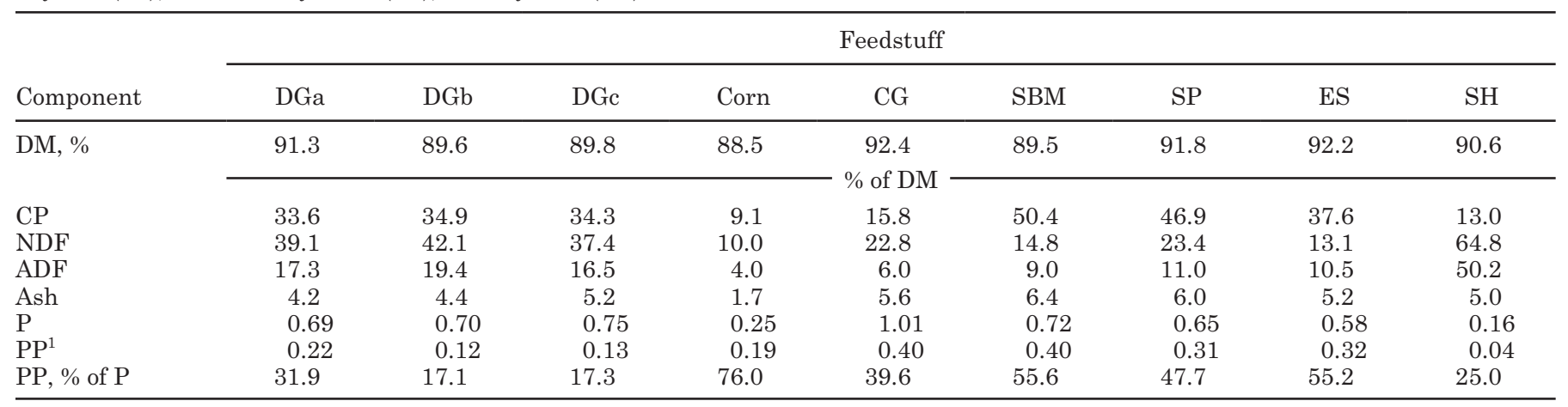

${ }^{1}$ Phytate phosphorus.

composition of the samples and the in situ procedures were described by Kleinschmit et al. (2007). Briefly, 2 ruminally cannulated lactating Holstein cows (261 and 265 DIM) producing 34 and $29 \mathrm{~kg} / \mathrm{d}$ of milk were fed, for ad libitum consumption, a diet consisting of $40 \%$ forage and $60 \%$ concentrate on a DM basis (Table 1). In both experiments cows were allowed a 14-d diet adjustment period before the initiation of the in situ procedure. Samples were prepared similarly as in experiment 1 . Incubation measures were completed at 3 , $6,12,18,24$, and $36 \mathrm{~h}$ over 2 periods. Immediately after removal of the bags from the rumen, the mesh bag was gently agitated in tap water to remove small particles. Individual nylon bags were further rinsed with cold tap water until the water became clear.

\section{Chemical Analysis}

Original test feedstuffs were analyzed for DM, CP, and ash (AOAC, 1995), NDF (Van Soest et al., 1991), $\mathrm{ADF}$ (Robertson and Van Soest, 1981) using an Ankom fiber analyzer with the filter bag technique (Ankom
Technology Corp., Fairport, NY), and phytate phosphorus (Haug and Lantzsch, 1983). Phosphorus concentration was determined spectrophotometrically by the molybdo-vanadate reagent after mineralization of samples with $6 \mathrm{M} \mathrm{HCl}$ (AOAC, 1995; method 965.17) using a model DU70 Beckman spectrophotometer (Beckman Instruments Inc., Fullerton, CA). Chemical composition of the feedstuffs is presented in Table 2 (experiment 1) and Table 3 (experiment 2).

After removal from the rumen, bags were dried for $48 \mathrm{~h}$ at $55^{\circ} \mathrm{C}$ in a forced air oven, and then residues were weighed and analyzed for DM and $\mathrm{P}$ as described. Dry matter and $\mathrm{P}$ disappearance were calculated by difference of original amounts and residual amounts after ruminal incubation.

\section{Mathematical and Statistical Analysis}

In situ degradation curves of $\mathrm{DM}$ and $\mathrm{P}$ were fitted to a nonlinear model (Ørskov and McDonald (1979):

$$
\mathrm{Y}=\mathrm{A}+\mathrm{B}\left(1-\mathrm{e}^{-\mathrm{kd}(\mathrm{t})}\right),
$$

Table 3. Chemical composition of dried distillers grains with solubles (DG1, DG2, DG3) and wet distillers grains with solubles (WDG) examined in experiment 1 (Adapted from Kleinschmit et al., 2007)

\begin{tabular}{lcccc}
\hline & \multicolumn{4}{c}{ Feedstuff } \\
\cline { 2 - 5 } Item & DG1 & DG2 & DG3 & WDG \\
\hline DM, \% & 89.6 & 88.2 & 90.7 & 31.6 \\
\cline { 2 - 5 } & & & & \\
CP & 31.3 & 33.5 & 30.6 & 32.6 \\
$\mathrm{NDF}$ & 37.4 & 29.5 & 35.9 & 38.6 \\
$\mathrm{ADF}$ & 20.3 & 14.7 & 14.7 & 15.7 \\
Ash & 4.58 & 5.38 & 4.46 & 3.77 \\
$\mathrm{P}$ & 0.84 & 0.74 & 0.71 & 0.56 \\
$\mathrm{PP} 1$ & 0.29 & 0.24 & 0.26 & 0.26 \\
$\mathrm{PP}, \%$ of $\mathrm{P}$ & 34.5 & 32.4 & 36.6 & 46.4 \\
\hline
\end{tabular}

${ }^{1}$ Phytate phosphorus. 
Table 4. Rumen dry matter degradation parameters for dried distillers grains with solubles (DGa, DGb, DGc), corn, corn germ (CG), soybean meal (SBM), SoyPlus (SP), extruded soybeans (ES), and soyhulls (SH)

\begin{tabular}{|c|c|c|c|c|c|c|c|c|c|c|}
\hline Parameter $^{1}$ & \multicolumn{9}{|c|}{ Feedstuff } & SEM \\
\hline $\mathrm{A}_{\mathrm{DM}}, \%$ & $34.9^{\mathrm{d}}$ & $42.2^{\mathrm{c}}$ & $47.9^{\mathrm{a}}$ & $37.3^{\mathrm{d}}$ & $44.1^{\mathrm{abc}}$ & $43.7^{\mathrm{bc}}$ & $43.0^{\mathrm{bc}}$ & $46.4^{\mathrm{ab}}$ & $30.5^{\mathrm{e}}$ & 2.34 \\
\hline $\mathrm{K}_{\mathrm{dDM}}, \% / \mathrm{h}$ & $4.64^{\mathrm{ab}}$ & $2.86^{\mathrm{c}}$ & $5.00^{\mathrm{ab}}$ & $5.89^{\mathrm{ab}}$ & $6.84^{\mathrm{ab}}$ & $7.47^{\mathrm{a}}$ & $5.00^{\mathrm{ab}}$ & $6.85^{\mathrm{ab}}$ & $4.12^{\mathrm{ab}}$ & 0.01 \\
\hline $\mathrm{ED}_{\mathrm{DM}}, \%$ & $60.7^{\mathrm{c}}$ & $59.5^{\mathrm{c}}$ & $65.1^{\mathrm{bc}}$ & $66.0^{\mathrm{bc}}$ & $72.2^{\mathrm{a}}$ & $73.3^{\mathrm{a}}$ & $66.8^{\mathrm{abc}}$ & $71.4^{\mathrm{a}}$ & $58.6^{\mathrm{d}}$ & 2.45 \\
\hline
\end{tabular}

${ }^{\mathrm{a}-\mathrm{e}}$ Within the same row, means with different superscripts differ significantly $(P<0.05)$.

${ }^{1} \mathrm{~A}_{\mathrm{DM}}=$ rapidly degradable fraction of $\mathrm{DM} ; \mathrm{B}_{\mathrm{DM}}=$ potentially degradable fraction of $\mathrm{DM} ; \mathrm{K}_{\mathrm{dDM}}=$ rate of degradation of fraction $\mathrm{B}_{\mathrm{DM}}$; and $\mathrm{ED}$ DM $=$ effective degradation of DM.

where $\mathrm{A}$ = rapidly degradable DM $\left(\mathbf{A}_{\mathrm{DM}}\right)$ or soluble $\mathrm{P}$ $\left(\mathbf{A}_{\mathbf{P}}\right)$ that disappeared at $0 \mathrm{~h}$ after the rinsing procedure; $\mathrm{B}=$ potentially degradable DM $\left(\mathbf{B}_{\mathbf{D M}}\right)$ or releasable $\mathrm{P}$ $\left(\mathbf{B}_{\mathbf{P}}\right) ; \mathrm{K}_{\mathrm{d}}=$ constant rate of DM degradation $\left(\mathbf{K}_{\mathrm{dDM}}\right)$ or $\mathrm{P}$ disappearance of the fraction $\mathrm{B}\left(\mathbf{K}_{\mathrm{dP}}\right)$; and $t=$ time of incubation, h. The unreleasable fraction $\left(\mathbf{C}_{\mathbf{P}}\right)$ was calculated as $100-A_{P}-B_{P}$. Effective $D M$ degradability and $\mathrm{P}$ disappearance were determined assuming a passage rate from the rumen of $6 \% / \mathrm{h}$ by the equation:

$$
\mathrm{ED}=\mathrm{A}+\mathrm{B}\left[\mathrm{K}_{\mathrm{d}} /\left(\mathrm{K}_{\mathrm{d}}+\mathrm{Kp}\right)\right]
$$

where $\mathrm{Kp}$ is the passage rate from the rumen $(\% / \mathrm{h})$, and $\mathrm{A}, \mathrm{B}$, and $\mathrm{K}_{\mathrm{d}}$ are the degradation constants described previously (Ørskov and McDonald, 1979).

Degradation or disappearance constants of DM or $\mathrm{P}$ described above were estimated using the NLIN procedure of SAS (SAS Institute, 2001). Phosphorus disappearance at each time point was analyzed using the MIXED procedure of SAS (SAS Institute, 2001) with cow as a random variable. The model for experiment 1 included the fixed effects of treatment, time, and treatment $\times$ time. The model for experiment 2 included fixed effects of treatment, time, period, and treatment $\times$ time. In situ disappearance constants and effective disappearance were analyzed using the MIXED procedure of SAS (SAS Institute, 2001) for each feed ingredient with cow as a random variable. The model used for experiment 1 included treatment as a fixed effect and the model for experiment 2 included fixed effects of treatment and period. Mean comparisons were performed by using the Tukey test with $P<0.05$ as the significant level.

\section{RESULTS}

\section{Experiment 1}

Phosphorus concentrations in corn and soybean feedstuffs ranged from 0.16 for $\mathrm{SH}$ to $1.01 \% \mathrm{DM}$ for CG, whereas $\mathrm{PP}$ ranged from 0.04 for $\mathrm{SH}$ to $0.40 \%$ for $\mathrm{SBM}$ and CG (Table 2). Concentrations of PP were twice as high in DGa compared with DGb and DGc. Distillers grains sources contained less PP compared with soybean products with the exception of $\mathrm{SH}$.

Dry matter A fraction was significantly different among feedstuffs and ranged from 30.5 to $47.9 \%$ (Table 4). Source DGc had the greatest $A_{D M}$ fraction, whereas SH contained the lowest $A_{D M}$ fraction. As a result, the $\mathrm{SH}$ showed greater $\mathrm{B}_{\mathrm{DM}}$ fraction $(P<0.05)$ and $\mathrm{DGc}$ had the least $\mathrm{B}_{\mathrm{DM}}$ among feedstuffs. The rate of $\mathrm{DM}$ disappearance was different among feedstuffs $(P<$ 0.05). Of the feeds tested, SBM had significantly the greatest DM degradation rate, whereas DGb had the lowest $K_{\mathrm{dDM}}$. The remaining feedstuffs (DGa, DGc, corn, $\mathrm{CG}, \mathrm{SP}$, ES, and $\mathrm{SH}$ ) had comparable $\mathrm{K}_{\mathrm{dDM}}$ averaging $5.47(\mathrm{SD} \pm 1.0) / \mathrm{h}$. Effective disappearance of $\mathrm{DM}$ varied from 73.3 to $58.6 \%$ and was high for SBM, CG, and $\mathrm{ES}[72.3(\mathrm{SD} \pm 0.90) \%]$, intermediate for $\mathrm{SP}, \mathrm{CG}$, and DGc [66.0 (SD \pm 0.85$) \%]$ and low for DGa, DGb, and $\mathrm{SH}[59.6(\mathrm{SD} \pm 1.05) \%]$.

A greater proportion of $\mathrm{P}$ disappeared compared with DM. The proportion of $\mathrm{P}$ determined to be immediately released $\left(\mathrm{A}_{\mathrm{P}}\right)$ differed $(P<0.05)$ among feedstuffs (Table 5). Sources DGc and DGb contained the greatest $\mathrm{A}_{\mathrm{P}}$ fraction among all feedstuffs, whereas $\mathrm{SH}$ contained the least amount of $\mathrm{P}$ in the $\mathrm{A}_{\mathrm{P}}$ fraction. As a result, greater potentially releasable $\mathrm{P}$ remained in $\mathrm{SH}$ $(P<0.05)$ compared with other feedstuffs. Fraction $\mathrm{B}_{\mathrm{P}}$ for SBM, SP, and ES was 32.9 ( $\mathrm{SD} \pm 2.20$ ) \%; ground corn and $\mathrm{CG}$ followed with a $\mathrm{B}_{\mathrm{P}}$ fraction estimated at $24.2(\mathrm{SD} \pm 2.96) \%$. Dried distillers grains had the least $\mathrm{B}_{\mathrm{P}}$ fraction among the feedstuffs, averaging 13.5 (SD $\pm 5.80) \%$ and did not differ across source indicating a rapid disappearance of $\mathrm{P}$ in the rumen. The unavailable fraction, $\mathrm{C}_{\mathrm{P}}$, was similar in all feedstuffs, ranging from $1.6 \%$ for $\mathrm{CG}$ to $9.4 \%$ for $\mathrm{SH}$. The rate of ruminal phosphorus disappearance, $\mathrm{K}_{\mathrm{dP}}$, was similar for all feedstuffs $(16.2 \pm 3.54 \% / \mathrm{h})$. Effective disappearance of $\mathrm{P}$ was greater for DDG (91.3 $\pm 2.37 \%), \mathrm{CG}$, and soy- 
Table 5. Rumen phosphorus disappearance parameters for DGa dried distillers grains with solubles (DGa, DGb, DGc), corn, corn germ (CG), soybean meal (SBM), SoyPlus (SP), extruded soybeans (ES), and soyhulls (SH)

\begin{tabular}{|c|c|c|c|c|c|c|c|c|c|c|}
\hline Parameter $^{1}$ & \multicolumn{9}{|c|}{ Feedstuff } & SEM \\
\hline $\mathrm{A}_{\mathrm{P}}, \%$ & $74.5^{\mathrm{b}}$ & $84.4^{\mathrm{a}}$ & $87.5^{\mathrm{a}}$ & $65.4^{\mathrm{c}}$ & $77.0^{\mathrm{b}}$ & $62.1^{\mathrm{c}}$ & $62.9^{\mathrm{c}}$ & $66.6^{\mathrm{c}}$ & $45.0^{\mathrm{d}}$ & 1.44 \\
\hline $\mathrm{B}_{\mathrm{P}}, \%$ & $20.2^{\mathrm{d}}$ & $10.7^{\mathrm{d}}$ & $9.7^{\mathrm{d}}$ & $27.0^{\mathrm{cd}}$ & $21.4^{\mathrm{cd}}$ & $35.1^{\mathrm{bc}}$ & $33.0^{\mathrm{bc}}$ & $30.7^{\mathrm{bc}}$ & $45.6^{\mathrm{a}}$ & 3.25 \\
\hline $\mathrm{C}_{\mathrm{P}}, \%$ & 5.3 & 4.9 & 2.8 & 8.0 & 1.6 & 2.8 & 4.1 & 2.8 & 9.4 & 2.8 \\
\hline $\mathrm{K}_{\mathrm{dP}}, \% / \mathrm{h}$ & 24.6 & 15.5 & 14.1 & 11.7 & 14.9 & 16.1 & 16.7 & 17.0 & 14.9 & 7.32 \\
\hline $\mathrm{ED}_{\mathrm{P}}, \%$ & $88.8^{\mathrm{ab}}$ & $91.7^{\mathrm{a}}$ & $93.5^{\mathrm{a}}$ & $83.6^{\mathrm{b}}$ & $93.3^{\mathrm{a}}$ & $87.5^{\mathrm{ab}}$ & $87.0^{\mathrm{ab}}$ & $88.0^{\mathrm{ab}}$ & $69.0^{\mathrm{c}}$ & 2.88 \\
\hline
\end{tabular}

${ }^{\mathrm{a}-\mathrm{d}}$ Within the same row, means with different superscripts differ significantly $(P<0.05)$.

${ }^{1} \mathrm{~A}_{\mathrm{P}}=$ rapidly soluble fraction of $\mathrm{P} ; \mathrm{B}_{\mathrm{P}}=$ potentially releasable fraction of $\mathrm{P} ; \mathrm{C}_{\mathrm{P}}=$ unavailable fraction of $\mathrm{P}$; $\mathrm{K}_{\mathrm{dP}}=$ rate of $\mathrm{P}$ disappearance of fraction $\mathrm{B}_{\mathrm{P}}$; and $\mathrm{ED}_{\mathrm{P}}=$ effective disappearance of $\mathrm{P}$

bean products $(87.5 \pm 0.50 \%)$ with the exception of $\mathrm{SH}$ in which the $\mathrm{ED}_{\mathrm{P}}$ was the lowest among tested feedstuffs.

In the first $2 \mathrm{~h}$ of ruminal incubation, $\mathrm{SH}$ had the fastest $\mathrm{P}$ release among all feedstuffs where it increased from 41.9 to $59.7 \%$ between 0 and $2 \mathrm{~h}$ (Table 6). Corn byproducts and SP had a relatively fast rate of ruminal disappearance of P, whereas SBM and ES had the lowest extent of $\mathrm{P}$ disappearance in the first 2 $\mathrm{h}$ of ruminal incubation. The extent of $\mathrm{P}$ disappearance was greater for SBM than for corn byproducts during the first $12 \mathrm{~h}$ of ruminal incubation. The percentage of $\mathrm{P}$ disappearance increased from 66.2 and $92.9 \%$ for SBM from 2 to $12 \mathrm{~h}$, whereas in DDG, $\mathrm{P}$ disappearance only slightly increased from 87.6 to $90 \%$. The extent of $\mathrm{P}$ disappearance tended to be similar for all feedstuffs after $12 \mathrm{~h}$ of incubation, as the extent of $\mathrm{P}$ release reached its maximum between 18 and $48 \mathrm{~h}$ depending on the feedstuff.

\section{Experiment 2}

Concentrations of P for DDG (Table 3) ranged from 0.71 to $0.84 \%$ of $\mathrm{DM}$ and in average were greater than WDG $(0.56 \%)$. These values are similar to reported concentrations (Belyea et al., 2006). Concentrations of
PP were similar in all distillers grains samples $(0.26 \%)$. However, $\mathrm{PP}$ as a percentage of $\mathrm{P}$ was greater in WDG (46.4\%) compared with DDG (34.5\%). Nutrient composition of the different distillers grains was similar in CP (32.0\%) and NDF (35.4\%).

Phosphorus disappearance kinetics in different distillers grains samples is presented in Table 7. The percentage of $\mathrm{P}$ immediately released, $\mathrm{A}_{\mathrm{P}}$, differed among the DDG sources $(P<0.05)$. Source DG3 had the greatest $A_{P}$ fraction followed in order by DG2, DG1, and WDG. The range of fraction $\mathrm{B}_{\mathrm{P}}$ (representing the slowly released P) was 8.9 (DG1) to $15.8 \%$ (WDG). The DDG samples averaged 9.5 (SD \pm 0.60$) \%$. The unavailable fraction of $\mathrm{P}, \mathrm{C}_{\mathrm{P}}$, was greater $(P<0.05)$ in DG1, intermediate in DG2 and WDG, and smallest in DG3. Disappearance rate, $K_{d P}$, did not differ among the different sources of distillers grains. The $\mathrm{ED}_{\mathrm{P}}$ ranged from 88.1 to $92.8 \%(P<0.05)$. The DG1 and DG3 had the greatest $\mathrm{ED}_{\mathrm{P}}$ among the different sources, followed by DG2 and WDG. During the first $12 \mathrm{~h}$ of ruminal incubation, the extent of $\mathrm{P}$ disappearance was faster in DG1 compared with the other sources because of rapid release within $3 \mathrm{~h}$ of rumen incubation (Table 8 ). In the intermediate incubation phase (12 to $24 \mathrm{~h}$ ), $\mathrm{P}$ release from DG1 was negligible, probably because most of the available $\mathrm{P}$ disappeared within the first $12 \mathrm{~h}$, whereas

Table 6. Phosphorus disappearance after ruminal incubation for dried distillers grains with solubles (DGa, DGb, and DGc), corn, corn germ (CG), soybean meal (SBM), SoyPlus (SP), extruded soybeans (ES), and soyhulls (SH)

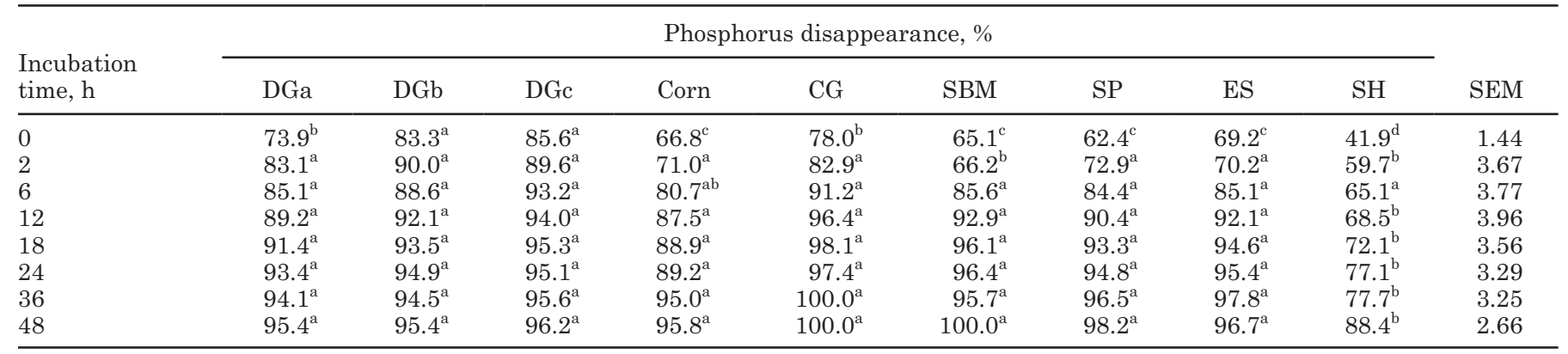

${ }^{\mathrm{a}-\mathrm{d}}$ Within the same row, means with different superscripts differ significantly $(P<0.05)$. 
Table 7. Rumen phosphorus disappearance parameters from dried distillers grains with solubles (DG1, DG2, DG3), and wet distillers grains with solubles (WDG)

\begin{tabular}{lccccc}
\hline & \multicolumn{4}{c}{ Feedstuff } & \multirow{2}{*}{ SEM } \\
\cline { 2 - 5 } Parameter $^{1}$ & DG1 & DG2 & DG3 & WDG & W \\
\hline $\mathrm{A}_{\mathrm{P}}, \%$ & $84.1^{\mathrm{c}}$ & $86.4^{\mathrm{b}}$ & $90.3^{\mathrm{a}}$ & $82.7^{\mathrm{d}}$ & 0.21 \\
$\mathrm{~B}_{\mathrm{P}}, \%$ & $8.9^{\mathrm{b}}$ & $10.1^{\mathrm{b}}$ & $9.6^{\mathrm{b}}$ & $15.8^{\mathrm{a}}$ & 1.31 \\
$\mathrm{C}_{\mathrm{P}}, \%$ & $7.0^{\mathrm{a}}$ & $3.4^{\mathrm{b}}$ & $0.1^{\mathrm{c}}$ & $1.5^{\mathrm{b}}$ & 1.85 \\
$\mathrm{~K}_{\mathrm{dP}} \% / \mathrm{h}$ & 7.0 & 5.0 & $2.0^{\mathrm{a}}$ & 4.1 & 0.80 \\
$\mathrm{ED}, \%$ & $92.1^{\mathrm{a}}$ & $89.8^{\mathrm{b}}$ & $92.8^{\mathrm{a}}$ & $88.1^{\mathrm{b}}$ & 0.45 \\
\hline
\end{tabular}

${ }^{a-d}$ Within the same row, means with different superscripts differ significantly $(P<0.05)$.

${ }^{1} \mathrm{~A}_{\mathrm{P}}=$ rapidly soluble fraction of $\mathrm{P} ; \mathrm{B}_{\mathrm{P}}=$ potentially releasable fraction of $\mathrm{P} ; \mathrm{C}_{\mathrm{P}}=$ unavailable fraction of $\mathrm{P}$; $\mathrm{K}_{\mathrm{dP}}=$ rate of $\mathrm{P}$ disappearance of fraction $\mathrm{B}_{\mathrm{P}}$; and $\mathrm{ED}_{\mathrm{P}}=$ effective disappearance of $\mathrm{P}$.

in WDG, the extent of $\mathrm{P}$ release increased from 86.9 to 91.2\%. The extent of $\mathrm{P}$ disappearance during the last $12 \mathrm{~h}$ of incubation was low and comparable in all distillers grains sources indicating that $\mathrm{P}$ disappearance tended to attain its maximum, averaging $94.2 \%$ at $36 \mathrm{~h}$ of ruminal incubation.

\section{DISCUSSION}

A good understanding of $\mathrm{P}$ digestion and metabolism in ruminants is critical to improve the efficiency of $\mathrm{P}$ utilization and minimize the pollution risk associated with overfeeding $\mathrm{P}$. Utilization of $\mathrm{P}$ is a function of 2 processes that combine the disappearance of the element from feedstuffs and the animal absorption capacity of the fraction released in the rumen. Field (1981) stated that mineral absorption as well as utilization depends largely on solubility in the rumen. Therefore, $\mathrm{P}$ disappearance is an important precondition of its utilization in animals.

\section{Experiment 1}

Few estimates of DM degradation in soybean products and DDG are available for comparison. Dry matter A fractions for the different DDG samples were similar to those in the report of Batajoo and Shaver (1998; 40.2\%). Dry matter A fraction for SBM was greater than the value reported by Batajoo and Shaver (1998; 35.4\%) and Ganesh and Grieve (1990; 21.3\%) but similar to the value reported by Armentano et al. (1986; 44.0\%). Dry matter disappearance rate varied by source of DDG ranging from 2.86 to $5.00 \% / \mathrm{h}$. Similar values have been reported by Batajoo and Shaver (1998) and DePeters et al. (1997). Effective disappearance of DM was similar to reported values for DDG and greater for SBM (Batajoo and Shaver, 1998). Differences in DM kinetics between our study and others may be explained by several factors such as feed particle size (Nocek, 1985; Cerneau and Michalet-Doreau, 1991), bag surface area ratio (Mehrez and Ørskov, 1977), sample size, origin of grains, bag material and pore size, diet fed during the measurement (Weakley et al., 1983; Nocek, 1985), and washing procedures (Cherney et al., 1990).

Phytate phosphorus averaged between 17 and $76 \%$ of the total $\mathrm{P}$ for the feedstuffs tested in this study. Phosphorus release depends upon hydrolysis of the phytate molecule. In ruminants, the inherent phytase activity of rumen microbes digests nearly all the PP into inorganic P (Reid et al., 1947; Raun et al., 1956; Soares, 1995). In theory, P should reach the same extent of release in different feedstuffs if allowed sufficient

Table 8. Phosphorus disappearance after ruminal incubation from dried distillers grains with solubles (DG1, DG2, DG3), and wet distillers grains with solubles (WDG)

\begin{tabular}{llllll}
\hline \multirow{2}{*}{$\begin{array}{l}\text { Incubation } \\
\text { time, } \mathrm{h}\end{array}$} & \multicolumn{3}{c}{ Phosphorus disappearance, \% } \\
\cline { 2 - 4 } & DG1 & DG2 & DG3 & WDG & SEM \\
\hline 0 & $84.1^{\mathrm{c}}$ & $86.4^{\mathrm{b}}$ & $90.3^{\mathrm{a}}$ & $82.7^{\mathrm{d}}$ & 0.21 \\
3 & $91.2^{\mathrm{a}}$ & $87.1^{\mathrm{b}}$ & $90.7^{\mathrm{a}}$ & $85.3^{\mathrm{c}}$ & 0.51 \\
6 & $92.3^{\mathrm{a}}$ & $88.9^{\mathrm{b}}$ & $91.5^{\mathrm{a}}$ & $85.7^{\mathrm{c}}$ & 0.77 \\
12 & $92.5^{\mathrm{a}}$ & $89.8^{\mathrm{ab}}$ & $92.3^{\mathrm{a}}$ & $86.9^{\mathrm{c}}$ & 1.00 \\
18 & $92.3^{\mathrm{a}}$ & $90.5^{\mathrm{a}}$ & $93.2^{\mathrm{a}}$ & $88.2^{\mathrm{b}}$ & 0.93 \\
24 & $93.1^{\mathrm{a}}$ & $91.2^{\mathrm{b}}$ & $93.8^{\mathrm{a}}$ & $91.2^{\mathrm{b}}$ & 0.90 \\
36 & 94.3 & 93.5 & 95.7 & 93.2 & 0.46 \\
\hline
\end{tabular}

${ }^{\mathrm{a}-\mathrm{d}}$ Within the same row, means with different superscripts differ significantly $(P<0.05)$. 
incubation in the rumen. However, in high-producing dairy cows this may not be true as rumen dilution rates are high, resulting in $\mathrm{PP}$ that escapes the rumen in undigested grains (Clark et al., 1986).

The readily soluble fraction of $\mathrm{P}\left(\mathrm{A}_{\mathrm{P}}\right)$ in $\mathrm{SBM}$ from this experiment was greater than the value reported by Bravo et al. (2000; 49.0\%). However, the effective disappearance of $\mathrm{P}$ was similar. Differences may be explained by experimental procedures, genetic variation, and processing variations. Regarding DDG, the $\mathrm{ED}_{\mathrm{P}}$ was noticeably greater in the current experiment (91.3\%) compared with the $\mathrm{ED}_{\mathrm{P}}$ reported by Bravo et al. $(2000 ; 66.4 \%)$. The corn distillers tested in that study originated from a corn in which the germ was completely removed. Phosphorus in that product $(0.08 \%)$ was probably integrated as a structural part and therefore not easily released in the rumen. Similar to our results, the disappearance of $\mathrm{P}$ in phytate from SBM and DDG followed the same patterns when assessed using an in vitro method (Morse et al., 1992). Phosphorus in phytate was rapidly degraded in DDG compared with SBM (71.3 vs. 36.3\%) after $1 \mathrm{~h}$ of in vitro incubation and maximal $\mathrm{P}$ disappearance from SBM required longer incubation time compared with DDG (Morse et al., 1992).

Soybean products, with the exception of $\mathrm{SH}$, tend to have greater $\mathrm{CP}$ and $\mathrm{PP}$ concentrations compared with DDG. Phytate molecules form stable complexes with protein (Thomas et al., 1946) and it becomes less available to the animal when protein concentration increases (Fontaine et al., 1946). Chemical bonds formed between protein and PP must be broken before inorganic $\mathrm{P}$ can be released from the phytate molecules (Fontaine et al., 1946). This may explain the greater disappearance rate of $\mathrm{P}$ in DDG compared with soybean products during the first $2 \mathrm{~h}$ of rumen incubation. On the other hand, the greater ruminal disappearance of $\mathrm{P}$ in DDG may be attributable to fermentation during ethanol production in which a considerable portion of PP in the corn is hydrolyzed. This hydrolysis of PP yields inorganic $\mathrm{P}$ that is readily available to the animal (Cromwell, 1979). Phosphorus disappearance kinetics was affected by the source of DDG. The DGa source contained more $\mathrm{P}$ as $\mathrm{PP}$ and resulted in a lower $\mathrm{A}_{\mathrm{P}}(P<$ 0.05) and a numerical decrease in $\mathrm{ED}_{\mathrm{P}}$ compared with other sources of DDG. Processing methods and heat treatment applied to the different samples may contribute to these differences. These results suggest that the DGa sample may have been subjected to moderate heat damage during processing.

Soybean meal, SP, and ES are soybean byproducts that differ considerably in protein degradability in the rumen. Konishi et al. (1999) reported that treatments that lower protein degradability in the rumen, such as temperature, might decrease the rate and extent of phytate degradation. However, in this experiment SBM, SP, and ES showed similar P disappearance kinetics. Phosphorus release was distinctly low in $\mathrm{SH}$. The high NDF concentration in $\mathrm{SH}$ (49\% of DM) may partially explain the low $\mathrm{ED}_{\mathrm{P}}$. Emanuele and Staples (1990) reported that high NDF concentrations negatively affected ruminal $\mathrm{P}$ release in forages. Furthermore, $\mathrm{P}$ in $\mathrm{SH}$ may be integrated as a structural part of the cell walls and it may require longer incubation time in the rumen to be released. Finally, $\mathrm{P}$ was readily soluble in CG compared with ground corn. More than $90 \%$ of the phytate in corn is found in the germ portion of the kernel (Ravindran et al., 1995) and when germ is extracted from the grain, $\mathrm{P}$ is also extracted because corn $\mathrm{P}$ is concentrated in the germ (Pointillart, 1994). Thus, the peripheral parts of corn need to be digested first in order for the $\mathrm{P}$ to be released, whereas in $\mathrm{CG}$, such structural parts do not exist, allowing for fast access of phytase by microbes in the rumen.

\section{Experiment 2}

Variations in $\mathrm{P}$ concentrations among the DDG sources were most likely due to differences in processing techniques and conditions among ethanol plants. Dried distillers grains with solubles are made by blending condensed distillers solubles (also referred to as syrup) with wet grains. Condensed distillers solubles contain high concentrations of $\mathrm{P}(1.52 \%)$, whereas wet grains contain approximately $0.54 \%$ (Belyea et al., 2006). Consequently, considerable differences in $\mathrm{P}$ concentrations among distillers grains are likely to occur because of variable amounts of condensed distillers solubles added back to wet grains to make the final product.

Dried distillers grains contained more $P$ in the $A_{P}$ fraction and less in the $\mathrm{B}_{\mathrm{P}}$ fraction compared with WDG resulting in a greater $\mathrm{ED}_{\mathrm{P}}$ in DDG. The greater concentration of $\mathrm{PP}$ as percentage of total $\mathrm{P}$ in WDG compared with DDG (46.5 vs. $34.4 \%$, respectively) could explain these differences. Although it is unknown how much condensed distillers solubles was added back to create each distillers grains feedstuff, the lower P concentration in WDG implies that less syrup may have been included in this WDG sample. Consequently, a greater proportion of the total P in the WDG was PP compared with the other DDG feedstuffs. Phosphorus contained in the phytate molecule requires longer fermentation before it can be released.

In this study, differences existed among the DDG samples; DG3 showed greater $\mathrm{A}_{P}$ fraction and $\mathrm{ED}_{\mathrm{P}}$ compared with other samples, whereas DG1 had the lowest $A_{P}$ fraction among the $D D G$ and the greatest $C_{P}$ 
fraction (7.0\%). Kleinschmit et al. (2007) reported that geometric mean diameters for DG1, DG2, and DG3 were $0.74,1.01$, and $0.46 \mathrm{~mm}$, respectively, making loss of particles from the bag an unlikely explanation for the high soluble fraction of $\mathrm{P}\left(\mathrm{A}_{\mathrm{P}}\right)$ for the distillers grains samples. In addition, Kleinschmit et al. (2007) reported ruminally effective degradability of $\mathrm{CP}$ (RDP) to be $28.3,32.5,39.7$, and $46.4 \%$ for DG1, DG2, DG3, and WDG, respectively, demonstrating that although $\mathrm{P}$ disappearance of DDG in the rumen is quite high, $\mathrm{CP}$ disappearance is not.

The DG1 had a much greater proportion of CP in the unavailable fraction and less in the soluble fraction compared with other sources, suggesting that DG1 may have been excessively heated. On the contrary, the extent of $\mathrm{P}$ release in DG1 was not depressed indicating that drying temperature in processing DG1 was not enough to adversely affect the disappearance of $\mathrm{P}$. Heating treatment, however, is not likely the only factor that may affect ruminal $\mathrm{P}$ disappearance. Other factors such as genetic variations or other technological procedures likely contributed to differences between samples. A wide range of distillers grains from different processing plants is needed to assess the effect that heating, processing, and other factors have on $\mathrm{P}$ disappearance in the rumen.

\section{CONCLUSIONS}

In situ results from both experiments confirmed that distillers grains, corn germ, and soybean products have high ruminal disappearance of $\mathrm{P}(>88.0 \%)$. The extent of $\mathrm{P}$ disappearance was similar for all sources of DDG in spite of differences in the readily soluble $\mathrm{P}$ in the rumen. Wet distillers grains had less effective disappearance of $\mathrm{P}$ in the rumen compared with DDG. The high $\mathrm{P}$ disappearance from DDG in the rumen of dairy cows suggests that the need of supplementing inorganic $\mathrm{P}$ would become unnecessary when diets contain adequate amounts of DDG.

\section{ACKNOWLEDGMENTS}

The authors wish to acknowledge the South Dakota Agricultural Experiment Station and the South Dakota Corn Utilization Council (Sioux Falls, SD) for partial financial support. The authors also thank Daryl Kleinschmit and Jill Anderson for technical assistance.

\section{REFERENCES}

AOAC. 1995. Official Methods of Analysis. Vol. I. 15th ed. Association of Official Analytical Chemists, Gaithersburg, MD.

Armentano, L. E., T. A. Herrington, C. E. Polan, A. J. Moe, J. H. Herbein, and P. Umstadt. 1986. Ruminal degradation of dried brewer's grains, wet brewer's grains, and soybean meal. J. Dairy Sci. 69:2124-2133.

Batajoo, K. K., and R. D. Shaver. 1998. In situ dry matter, crude protein, and starch degradabilities of selected grains and byproducts. Anim. Feed Sci. Technol. 71:165-176.

Belyea, R. L., T. E. Clevenger, V. Singh, M. E. Tumbleson, and K. D. Rausch. 2006. Element concentrations of dry-grind cornprocessing streams. Appl. Biochem. Biotechnol. 134:113-128.

Bravo, D., F. Meshy, C. Bogaert, and D. Sauvant. 2000. Ruminal phosphorus availability from several feedstuffs measured by the nylon bag technique. Reprod. Nutr. Dev. 40:149-162.

Cerneau, P., and B. Michalet-Doreau. 1991. In situ starch degradation of different feeds in the rumen. Reprod. Nutr. Dev. 31:65-72.

Cherney, D. J. R., J. A. Patterson, and R. P. Lemenager. 1990. Influence of in situ bag rinsing technique on determination of dry matter disappearence. J. Dairy Sci. 73:391-397.

Clark, W. D. Jr., J. E. Wohlt, R. L. Gilbreath, and P. K. Zajak. 1986. Phytate phosphorus intake and disappearance in the gastrointestinal tract of high producing dairy cows. J. Dairy Sci. 69:3151-3155.

Cromwell, G. L. 1979. Availability of phosphorus in feedstuffs for swine. Distillers Feed Res. Council. 34:40-52.

DePeters, E. J., J. G. Fadel, and A. Arosemena. 1997. Digestion kinetics of neutral detergent fiber and chemical composition within some selected byproducts feedstuffs. Anim. Feed Sci. Technol. 67:127-140.

Emanuele, S. M., and C. R. Staples. 1990. Ruminal release of minerals from six forage species. J. Anim. Sci. 68:2052-2060.

Field, A. C. 1981. Some thoughts on dietary requirements of macroelements for ruminants. Proc. Nutr. Soc. 40:267-272.

Flachowsky, G., M. Grün, S. Polzin, and H. Kronemann. 1994. In sacco dry matter degradability and $\mathrm{Ca}, \mathrm{Mg}$ and $\mathrm{P}$ disappearance from Italian ryegrass, alfalfa hay and wheat straw in sheep and goats. J. Anim. Physiol. Anim. Nutr. (Berl.) 71:57-64.

Fontaine, T. D., W. A. Pons Jr., and G. W. Irving Jr. 1946. Proteinphytic acid relationship in peanuts and cottonseed. J. Biol. Chem. 164:487-507.

Ganesh, D., and D. G. Grieve. 1990. Effects of roasting raw soybeans at three temperatures on in situ dry matter and nitrogen disappearance in dairy cows. J. Dairy Sci. 73:3222-3230.

Haug, W., and H. J. Lantzsch. 1983. Sensitive method for the rapid determination of phytate in cereals and cereal products. J. Sci. Food Agric. 34:1423-1426.

Hristov, A. N., A. Melgar, A. E. Foley, and R. Kincaid. 2004. Ruminal degradability of nitrogen, phosphorus, and potassium from dairy feedstuffs. J. Anim. Sci. 82(Suppl. 1):49. (Abstr.)

Kleinschmit, D. H., J. L. Anderson, D. J. Schingoethe, K. F. Kalscheur, and A. R. Hippen. 2007. Ruminal and intestinal digestibility of distillers grains plus solubles varies with source. J. Dairy Sci. 90:2909-2918.

Konishi, C., T. Matsui, W. Park, H. Yano, and F. Yano. 1999. Heat treatment of soybean meal and rapeseed meal suppresses rumen degradation of phytate phosphorus in sheep. Anim. Feed Sci. Technol. 80:115-122.

Martz, F. A., A. T. Belo, M. F. Weiss, R. L. Belyea, and J. P. Goff. 1990. True absorption of calcium and phosphorus from alfalfa and corn silage when fed to lactating cows. J. Dairy Sci. 82:618622.

Mehrez, A. A., and E. R. Orskov. 1977. A study of the artificial bag technique for determining the digestibility of feeds in the rumen. J. Agric. Sci. Camb. 88:645-650.

Morse, D., H. H. Head, and C. J. Wilcox. 1992. Disappearance of phosphorous in phytate from concentrates in vitro from rations fed to lactating dairy cows. J. Dairy Sci. 75:1979-1986.

National Research Council. 2001. Nutrient Requirements of Dairy Cattle. 7th rev. ed. National Academy Press, Washington, DC.

Nocek, J. E. 1985. Evaluation of specific variables affecting in situ estimates of ruminal dry matter and protein digestion. J. Anim. Sci. 60:1347-1358.

Ørskov, E. R., and I. McDonald. 1979. The estimate of protein degradability in the rumen from incubation measurements 
weighted according to rate of passage. J. Agric. Sci. 92:499503

Pedersen, C., M. G. Boersma, and H. H. Stein. 2007. Digestibility of energy and phosphorus in ten samples of distillers dried grains with solubles fed to growing pigs. J. Anim. Sci. 85:1168-1176.

Pointillart, A. 1994. Phytates, phytases: Leur importance dans l'alimentation des monogastiques. INRA Prod. Anim. 7:29-39.

Raun, A., E. Cheng, and W. Burroughs. 1956. Phytate phosphorus hydrolysis and availability to rumen microorganisms. J. Agric. Food Chem. 4:869-871.

Ravindran, V., W. L. Bryden, and E. T. Kornegay. 1995. Phytin Occurrence, bioavailability and implications in poultry nutrition. Poult. Avian Biol. Rev. 6:125-143.

Reid, R. L., M. C. Franklin, and E. G. Hallsworth. 1947. The utilization of phytate phosphorus by sheep. Aust. Vet. J. 23:136-140.

Robertson, J. B., and P. J. Van Soest. 1981. The detergent system of analysis and its application to human foods. Pages 123-158 in The Analysis of Dietary Fiber in Food. W. P. T. James and O. Theander, ed. Marcel Dekker Inc., New York, NY.
SAS Institute. 2001. SAS User's Guide. Statistics, Version 8 ed. SAS Institute, Inc., Cary, NC

Soares, J. H. 1995. Phosphorus bioavailability. Pages 257-294 in Bioavailability of Nutrients for Animals. C. B. Ammerman, D. H. Baker, and A. J. Lewis, ed. Academic Press, Inc., New York, NY.

Stern, M. D., G. A. Varga, J. H. Clark, J. L. Firkins, J. T. Huber, and D. L. Palmquist. 1994. Evaluation of chemical and physical properties of feeds that affect protein metabolism in the rumen. J. Dairy Sci. 77:2762-2786.

Thomas, D. F., A. P. Walter, and W. I. George. 1946. Protein-phytic acid relationship in peanuts and cottonseed. J. Biol. Chem. 164:487-507.

Van Soest, P. J., J. B. Robertson, and B. A. Lewis. 1991. Methods for dietary fiber, neutral detergent fiber, and nonstarch polysaccharides in relation to animal nutrition. J. Dairy Sci. 74:3583-3597.

Weakley, D. C., M. D. Stern, and L. D. Satter. 1983. Factors affecting disappearance of feedstuffs from bags suspended in the rumen. J. Anim. Sci. 56:493-507. 